\section{RIBOFLAVIN ENHANCEMENT OF RADIOACTIVE PHOSPHATE EXCHANGE BY YEASTS}

\author{
BY DR. WALTER J. NICKERSON* \\ AND \\ DR. LORIN J. MULLINS $†$ \\ Carlsberg Laboratorium and Institute for
}

$I^{1}$ $\mathrm{T}$ has recently been suggested by von Hevesy ${ }^{1}$ that processes occurring at the cell surfaces or just inside cell boundaries play an important part in phosphorus metabolism in yeast. We have obtained evidence that we interpret in a similar vein, and suggest the existence of a 'P-complexing factor' at the cell surface.

We have found it possible to increase the radioactive phosphate $\left(\mathrm{P}^{32}\right)$ exchanged by yeast in the presence of glucose by the addition of trace amounts of riboflavin to the suspending medium. The increases observed range from 20 to 200 per cent over the phosphate exchanged by controls in glucose alone. This effect has been found in two widely different species of yeasts.

The organisms used were Candida albicans, a pathogenic non-sporulating yeast, and Saccharomyces cerevisiae (Carlsberg No. 237). Cells were grown in wort or in a medium $(G G Y)$ consisting of : glucose, 2.0 gm.; glycine, l.0 gm. ; yeast extract ('Difco'), $0.1 \mathrm{gm}$.; and distilled water, $100 \mathrm{ml}$., and incubated for 24 hours at $20^{\circ}$ C. with constant agitation. The yeast crop was harvested by centrifugation, washed twice with glass-distilled water, and suspended in glass-distilled water to a known density. The $\mathbf{P}^{32}$ was usually introduced at this time. Aliquots of the suspension were placed in flasks (with a fritted glass aeration tube leading to the bottom of the flask) in the following medium: yeast suspension, $M / 5,000$ potassium dihydrogen phosphate, $M / 15$ glucose, water or riboflavin (50 $\mu$ gm./c.c.). The flasks were aerated with washed and filtered compressed air, or with 95 per cent nitrogen with 5 per cent carbon dioxide (passed through a heated copper coil). After the experimental period, the yeast cells were removed by centrifugation, washed twice with glass-distilled water and the yeast cream placed in aluminium dishes adapted for Geiger-Müller counting, and measured automatically ${ }^{2}$. The results obtained in the two experiments reported here are typical of those we have obtained in many other experiments.

Addition of riboflavin (1 $\mu \mathrm{gma} . /$ c.c. final concentration) to suspensions of Saccharomyces cerevisice or Candida albicans metabolizing glucose aerobically or anaerobically prompted a marked increase in $\mathbf{P}^{\mathbf{3 2}}$ exchange. As shown in Table 1 , this addition of riboflavin more than doubled the $\mathbf{P}^{\mathbf{3 2}}$ exchanged aerobically by $S$. cerevisice with either glucose or sucrose as source of carbohydrate. In the same experiment, 2,4 dinitrophenol in a concentration of $10^{-3} M$ inhibited $\mathrm{P}^{32}$ exchange approximately 40 per cent; this is in agreement with the inhibitory action of this substance on phosphate uptake by $S$. cerevisice reported by Hotchkiss ${ }^{3}$.

If a P-complexing factor is formed at the cell surface, it is possible that, once formed, it might act

- Fellow of the John Simon Guggenhelm Memorial Foundation.

$\dagger$ Merck Fellow of the National Research Council.
TABLE 1. S. cerevisice, GROWN AEROBICALLY IN $G G Y$ MEDIUM FOR Not starved ; exposed aerobically to $\mathrm{P}^{32}$ at $25^{\circ} \mathrm{C}$., for $5 \mathrm{hr}$. with treatments as listed (40 mgm. yeast dry wt. per vessel)

\begin{tabular}{|c|l|c|}
\hline Ve'ssel & \multicolumn{1}{|c|}{ Treatment } & $\begin{array}{c}\text { Counts/min./mgm. } \\
\text { dry wt. } \\
\text { (standard units) }\end{array}$ \\
\hline 1 & glucose + glycine & $13 \cdot 6$ \\
2 & sucrose + glycine & $12 \cdot 5$ \\
3 & glucose + glycine + 2,4 dinitrophenol & $7 \cdot 9$ \\
4 & gucrose + glycine + 2,4 dinitrophenol & $7 \cdot 5$ \\
5 & glucose + glycine + riboflavin & $30 \cdot 7$ \\
6 & sucrose + glycine + riboflavin & $32 \cdot 8$ \\
\hline
\end{tabular}

in the absence of the energy-yielding processes apparently necessary for its formation.' An experiment was conducted along these lines wherein $C$. albicans was incubated aerobically at $20^{\circ} \mathrm{C}$. in the presence of riboflavin and glucose, then equilibrated at $+4^{\circ} \mathrm{C}$. and exposed to $\mathbf{P}^{32}$. Table 2 shows that the starved suspension of the yeast exchanged twice as much $\mathrm{P}^{32}$ as the unstarved suspension (both suspensions were prepared from the same culture of yeast). It is also seen that riboflavin prompted a nearly four-fold increase in the exchange of $\mathrm{P}^{32}$ by the starved cells, but was without effect on the unstarved yeast. The occurrence of phosphate exchange at a very slow rate by yeast at $+4^{\circ} \mathrm{C}$. has been reported by Lindahl et al. ${ }^{5}$.

TABLE 2. C. albicans, GROWN AEROBICALLY IN 'TULACF' WORT AT $20^{\circ}$ C. FOR 26 HR. WITH AGITATION.

Half the suspension not starved (stored at $4^{\circ} \mathrm{C}$. for $18 \mathrm{hr}$.), the other half starved by agitating aerobically in water for 18 hours at $25^{\circ} \mathrm{C}$. Both suspensions treated as below for $2 \mathrm{hr}$. at $25^{\circ} \mathrm{C}$. aerobically with constant agitation (50 mgm. yeast dry wt. per vessel), then placed at $-4^{\circ} \mathrm{C}$. for 45 min. $\mathrm{P}^{32}$ was then added and flasks held at $+4^{\circ} \mathrm{C}$. in presence of $\mathrm{P}^{82}$ for $5 \mathrm{hr}$. Cells separated by centrifugation and washed in the cold

\begin{tabular}{|c|l|c|c|}
\hline Vessel & \multicolumn{1}{|c|}{ Treatment } & $\begin{array}{c}\text { Counts/min. } \\
\text { (standard units) }\end{array}$ & $\begin{array}{c}\text { Counts/min./mgm. } \\
\text { dry wt. }\end{array}$ \\
\hline & $\begin{array}{c}\text { Cells starved } \\
\text { glucose + riboflavin } \\
\text { glucose }\end{array}$ & 100 & $2 \cdot 2$ \\
2 & $\begin{array}{c}\text { Not starved } \\
\text { glucose + riboflavin } \\
4\end{array}$ & $\begin{array}{l}15 \cdot 2 \\
\text { glucose }\end{array}$ & $\begin{array}{l}15 \cdot 6 \\
0 \cdot 5\end{array}$ \\
\hline
\end{tabular}

The increase in rate of uptake of $\mathbf{P}^{32}$ in the residualphosphorus fraction (presumably metaphosphate ${ }^{11}$ ) of yeast brought about by cyanide ${ }^{6}$ might be considered in the light of the present data on riboflavin in view of the action shown by Pett ${ }^{2}$ for the increase in riboflavin synthesis by yeast treated with cyanide. Among the several compounds examined, yeast nucleic acid, uracil, and fructose 1,6 diphosphate proved without detectable effect on phosphorus exchange by $C$. albicans metabolizing glucose aerobically.

Yeasts are well known to be relatively rich in riboflavin, so it is rather surprising to find that added. riboflavin exerts such marked effects as we have noted. An average value for the riboflavin content of baker's yeast may be taken from Pett ${ }^{7}$ as 20-30 $\mu \mathrm{gm} . / \mathrm{gm}$. dry wt., of which $80-90$ per cent exists as bound riboflavin. In our experiments usually 30-50 mgm. dry weight of yeast was placed in each flask containing $50 \mathrm{ml}$; thus a total of approximately $1 \mu \mathrm{gm}$. of riboflavin was introduced into each flask with the yeast. If all this riboflavin were to have been released from the yeast (not possible under our conditions) a concentration of $0.02 \mu \mathrm{gm}$. riboflavin per $\mathrm{ml}$. would have resulted. The quantities of riboflavin introduced into each flask as impurities in the sugars and glycine (reagent quality, 
but not especially purified) are undoubtedly minute. While some species of the genus Candida are known ${ }^{8}$ to produce sufficient riboflavin on controlled lowiron media to colour the medium, we have never succeeded, using the strains of Candida albicans employed here, in obtaining more than very small yields of riboflavin with similar, purified, known-iron media.

While it is well known that the presence of extermal phosphate is not essential for the oxidation and assimilation of glucose by yeast suspensions ${ }^{2}$, it is also known that phosphate exchange $e^{4,6}$ and poly. merization (as measured by the increase in basophily ${ }^{11}$ ) are dependent on the presence of external metabolizable substrate.

In view of the correlation which has been pointed out $^{3}$ between the action of 2,4 dinitrophenol on the assimilation of carbon sources by micro-organisms and its action on the uptake or exchange of inorganic phosphate by micro-organisms, it is of interest to compare the action of riboflavin with that of other agents on these two processes. Such a comparison has been made in Table 3 (references noted). It appears there is a decided $1: 1$ correlation between the processes of phosphate uptake and assimilation of carbon by micro-organisms. At the concentrations stated, the agents listed in Table 3 are without effect on the rate of aerobic or anaerobic breakdown of carbon sources. The effect noted ${ }^{10}$ for riboflavin on assimilation was observed with the two organisms reported on in this paper. From concomitant investigations $^{10}$ on the variation in basophily of yeasts (see Wiame ${ }^{11}$ ), it is believed that the $1: 1$ correlation between assimilation and phosphate uptake results from the, possibly coupled, simultaneous polymerization by yeasts of inorganic phosphate (to polyphosphates) and of carbon sources (to carbohydrate polymers).

TABLE 3

\begin{tabular}{|c|c|c|c|}
\hline Substance & Concentration & $\begin{array}{l}\text { Assimilation } \\
\text { of } \\
\text { carbohydrate }\end{array}$ & $\begin{array}{l}\text { Uptake or ex- } \\
\text { change of } \\
\text { inorganic } \\
\text { phosphate }\end{array}$ \\
\hline $\begin{array}{l}\text { 2,4 Dinitrophenol } \\
\text { Sodium azide } \\
\text { Gramicidin* } \\
\text { Glucose } \\
\text { Riboflavin }\end{array}$ & $\begin{array}{c}10^{-4} M \\
10^{-6} M \\
40 \mu \mathrm{gm} \cdot / \mathrm{ml} . \\
10^{-3} \cdot M \\
2.5 \times 10^{-6} M\end{array}$ & $\begin{array}{l}\text { inhibited } \\
\text { inhibited } \\
\text { inhibited }^{9} \\
\text { a substrate } \\
\text { enhanced }^{10}\end{array}$ & $\begin{array}{l}\text { inhibited }{ }^{8} \\
\text { inhibited d,13 }^{3} \\
\text { inhibited }^{3} \\
\text { enhanced }{ }^{4,8} \\
\text { enhanced }\end{array}$ \\
\hline
\end{tabular}

* Acting on Staphylococci, other agents acting on yeast.

The observation of Malm ${ }^{12}$ that phosphate exchange by yeast is sensitive to the $p H$ of the medium can be taken as evidence that a surface reaction, easily affected by extermal $p \mathrm{H}$, is involved in phosphate exchange (see Myrbäck and Vasseur ${ }^{14}$ for an extended discussion of the considerations underlying this line of reasoning). It is unlikely that phosphate enters the yeast cell in an ionized form, and it seems reasonable that phosphate is brought through the cell barrier by uniting with some 'complexing substance' existing at the cell surface. The compound of this substance with phosphate may then dissociate, or in other manner lose phosphate to the cell (possibly to coenzyme I ; see Lindahl et al. ${ }^{5}$ ), and free 'complexing substance' to act again. From our observations we believe that such a role as postulated for the 'complexing substance' may be filled by riboflavin. Combined roles of phosphorus and hydrogen transference for trace-active substances may assume importance in considerations of in vivo processes.
We wish to thank Prof. Ø. Winge for facilities at the Carlsberg Laboratorium, Prof. G. Hevesy for most helpful discussion and for reading the manuscript, and Mr. K. Zerahn for his aid in carrying out the activity counts.

1 Hevesy, von G., Adv. in Enzym., 7, 111 (1947).
'Ambrosen, J., Madsen, B., Ottesen, J., and Zerahn,

Ambrosen, J., Madsen, B., Ottesen, J., and Zerahn, K., Acta Physiol Scand., 10, 195 (1945).

3 Hotchkiss, R. D., Adv. in Enzym., 4, 153 (1943).

'Mullins, L. J., Biol. Bull., 83, 326 (1942).

${ }^{5}$ Lindahl, P. E., Strindberg, B., Malm, M., and Lagergren, B. M., 746 (1946). 'Lawrence, J. H., Erf, L. A., and Tuttle, L. W., J. App. Phys., 12,
333 (1941).

7 Pett, L. B., Biochem. J., 29, 937 (1935).

Tanner, F. W., jun., Vojnovich, C., and van Lanen, J. M., Science, 101, 180 (1945).

${ }^{\circ}$ Clifton, C. E., Adv. in Enzym., 6, 269 (1946).

${ }^{10}$ Nickerson, W. J. (in the press).

${ }^{11}$ Wiame, J. M., Biochimica et Biophysica Acta, 1, 234 (1947).

${ }^{12} \mathrm{Malm}$, M., quoted in ref. 1 ; also Arkiv f. Kemi., 25 A, No. 1 (1947).

${ }^{13}$ Spiegelman, S., Kamen, M. D., and Dunn, R., Fed. Proc., 5, 99 (1946).

${ }^{14}$ Myrbäck, K., and Vasseur, E., Z. physiol. Chem., 277, 171 (1943).

\section{FACTORS INVOLVED IN THE DEACTIVATION OF PENICILLIN SOLUTIONS BY RUBBER TUBING}

\section{By DR. L. J. BELLAMY and C. H. WATT Royal Arsenal, Woolwich}

COWAN ${ }^{1}$ in 1945 demonstrated that aqueous 1 solutions of penicillin could lose up to 50 per cent of their antibiotic activity by simple passage through the rubber tube of a continuous-drip apparatus. These results were confirmed by Huelsbusch, Foter and Gibby ${ }^{2}$, who showed that certain samples of both natural and synthetic rubber could inactivate completely the penicillin in solution in twenty-four hours ; and also by Hughes ${ }^{3}$, who showed that no improvement was obtained by repeated washing of the tubes before use.

At the request of the Medical Research Council through the Ministry of Supply Advisory Service on Rubber, we have been investigating this problem in the hope that we should be able to throw some light on the mechanism of inactivation and on possible methods of improving the quality of rubber supplies. The main technological details will be published elsewhere, and the purpose of this communication is to give a summary of the results relevant to medical practice.

The Effect of Compounding Ingredients and of Vulcanization. Unfortunately, none of the early workers was in a position to supply information on the compounding ingredients other than rubber which were present in the tubes which they tested. These ingredients may well represent quite a large proportion of the total weight, and as some of them are highly active substances it was thought possible that the trouble might be due to one or more of these rather than to the rubber itself. On testing singly a number of such substances, including natural rubber, sulphur, zine oxide, stearic acid, paraffin wax and a number of accelerators of vulcanization-mercaptobenzthiazole, dibenzthiazyl disulphide, tetramethylthiuram disulphide, zinc diethyldithiocarbamate and 